\title{
Dietary Nutrient Dependent Variations on Natural-Killer Activity of the Leucocytes of Rainbow Trout
}

\author{
Viswanath Kiron, Akihiro Gunji, Nobuaki Okamoto*, Shuichi Satoh, \\ Yayoi Ikeda and Takeshi Watanabe \\ Department of Aquatic Biosciences, Tokyo University of Fisheries, \\ Konan 4, Minato, Tokyo 108, Japan
}

(Received January 5, 1993)

\begin{abstract}
Recent investigations in fish have revealed the dietary dependence of immunosurveillance. This report describes the evidence for dietary link of non-specific cytotoxic activity of natural-killer cells in rainbow trout. Fish were reared for varying periods in different experiments designed to determine the role of protein, essential fatty acid and zinc. Later the immune response was recorded by measuring the release of ${ }^{51} \mathrm{Cr}$ from labelled $\mathrm{P} 815$ mouse mastocytoma target cells after $8 \mathrm{~h}$ incubation. Leucocytes isolated from the head kidney of experimental fish were employed as effector cells.

Dietary protein does not have any effect on the natural-killer like activity of the leucocytes. The activity was low when the diets were deficient in essential fatty acid and zinc.
\end{abstract}

Elements of the natural immunity serve as the first file of organismic defense against pathogens. It includes the internal defensive cells which are comprised of phagocytes and natural-killer (NK) cells. The latter heterogenous group of lymphocytes capable of lysing certain cultured tumor cells and viral infected cells have been described in mammals by a number of investigators (Kiessling et al., 1975; Zarling et al., 1975; Rook, 1989). Mechanisms of cytotoxic immunity have received little attention in fish studies. Literature indicates that an identified population of non-specific effector cytolytic cells from fish is perhaps a phylogenetic precursor to mammalian NK cells (Graves et al., 1984). Such cells from the peripheral blood and kidney of fish have been found to possess spontaneous cytotoxic activity against mammalian cell lines (Hinuma et al., 1980; Evans et al., 1984; Morita et al., 1989). The occurrence of cytotoxic effector lymphocytes in response to heterologus antigenic cells in rainbow trout has been described by Sakai (1983).

The link between nutrition and immunity has been firmly established in man and other vertebrates. Recent investigations (Durve and Lovell, 1982; Blazer and Wolke, 1984; Li and Lovell, 1985; Hardie et al.,1990; Lall et al., 1990; Sheldon and Blazer,

\footnotetext{
* Author to whom correspondence should be addressed.
}

1991; Scarpa et al., 1992) on such relationship in fish have revealed the dietary dependence of immunosurveillance. It was therefore decided to probe if the natural-killer like activity of the defense cells is influenced by the provisions of major dietary nutrients-protein, lipid and a trace element.

\section{Materials and Methods}

Rainbow trout (Oncorhynchus mykiss) hailing from different stock were used for three separate experiments. The rearing system consisted of flowthrough tanks supplied with water regulated at $15 \pm$ $1^{\circ} \mathrm{C}$ at a rate of $600 \mathrm{ml} / \mathrm{min}$. Experiment $\mathrm{I}$ studied the role of protein. Laboratory reared fish (mean initial weight $152 \mathrm{~g}$ ) were put on a pre-feeding diet containing about $35 \%$ protein. After about a month when the fish were accustomed to purified diet, they were fed the experimental diets (Table 1), a zero protein diet (Group A) and two diets containing 35 and 50\% levels of protein (Group B and C, respectively). The fish were fed to satiation twice a day for three months prior to examining the NK activity.

The second experiment (II) examined the role of essential fatty acids (EFA). Rainbow trout fry started on commercial diet was soon offered a purified casein based lipid free diet during the five month preparatory period, at the end of which they had a 
Table 1. Composition of the diets for Experiment I

\begin{tabular}{lcrc}
\hline \hline Ingredients $(\mathrm{g} / 100 \mathrm{~g})$ & Group A & Group B & Group C \\
\hline Casein & 0 & 35.0 & 50.0 \\
Amino acid mixture & 1.3 & 1.3 & 1.3 \\
$\alpha$-Starch & 8.7 & 8.0 & 8.0 \\
Dextrin & 68.0 & 38.0 & 25.0 \\
Soybean oil and pollack & 15.0 & 7.0 & 5.0 \\
$\quad$ liver oil (3:2) & 1.6 & 1.6 & 1.6 \\
Vitamin mixture & 0.4 & 0.4 & 0.4 \\
Choline chloride & 5.0 & 5.0 & 5.0 \\
Mineral mixture & 0 & 3.7 & 3.7 \\
Cellulose & & &
\end{tabular}

mean weight of about $42 \mathrm{~g}$. The test diets offered (Table 2) were an EFA deficient diet (Group D; 5\% lipid as methyl ester of palmitic acid) and a sufficient diet (Group S; lipid as 2 and 3\% methyl esters of $n$ 3 highly unsaturated fatty acid [HUFA] and palmitic acid, respectively). The fish were fed to satiation twice a day during the three months.

The experiment (III) on trace element was intended to examine the influence of zinc on natural-killer activity in trout. Fish first-fed on a commercial diet until $1.3 \mathrm{~g}$ were given the experimental diets for one year. Three groups, $\mathrm{X}, \mathrm{Y}$ and $\mathrm{Z}$, were fed the zinc deficient, insufficient and sufficient diets (Table 3), respectively, twice a day until satiation. Group Y was intended to receive only limited benefits from supplemented zinc; the tricalcium phosphate contained in the type of fish meal restricts the availability of the zinc provided $(40 \mu \mathrm{g} / \mathrm{g}$ diet $)$.

Ten fish were reared in each of the above experimental groups. After the respective rearing periods, the natural-killer activity of the leucocytes of five to seven fish from each group was assessed as described below. The head kidney was removed from anaesthetised fish under sterile conditions and gently mashed through a steel sieve into RPMI 1640 medium (Nissui Pharmaceutical Co.). The cells were concentrated by centrifugation and washed two times before layering the suspension onto Histopaque 1077 (Sigma Diagnostics). It was again centrifuged at $450 \times g$ for $\mathbf{4 0} \mathrm{min}$ in order to collect the top buffy coat layer which contained more than $60 \%$ and $35 \%$ of lymphocytes and thrombocytes, respectively. After three successive washings with RPMI, the cells were introduced into the medium containing $10 \%$ heat inactivated fetal bovine serum. The cells were incubated at $20^{\circ} \mathrm{C}$ for $12 \mathrm{~h}$ in sterile culture tubes. The viability of the cells which thereafter served as
Table 2. Basal diet composition for Experiment II

\begin{tabular}{lc}
\hline \multicolumn{1}{c}{ Ingredient } & Quantity $(\mathrm{g} / 100 \mathrm{~g})$ \\
\hline Casein & 52.0 \\
Amino acid mixture & 1.3 \\
$\alpha$-Starch & 15.0 \\
Dextrin & 15.0 \\
Lipid* & 5.0 \\
Vitamin mixture & 1.1 \\
Choline chloride & 0.5 \\
Mineral mixture & 5.0 \\
Cellulose & 5.1 \\
\hline
\end{tabular}

* Diet for Group D: Palmitic acid only

Diet for Group S: Palmitic acid $60 \%$ \& n-3 highly unsaturated fatty acid (HUFA) $40 \%$.

Table 3. Composition of the diets for Experiment III

\begin{tabular}{|c|c|c|c|}
\hline Ingredient $(\mathrm{g} / 100 \mathrm{~g})$ & Group X & Group Y & Group Z \\
\hline White fish meal ${ }^{* 1}$ & 55.0 & 55.0 & - \\
\hline White fish meal ${ }^{* 2}$ & - & - & 55.0 \\
\hline$\alpha$-Starch & 20.0 & 20.0 & 20.0 \\
\hline Dextrin & 5.0 & 5.0 & 5.0 \\
\hline $\begin{array}{l}\text { Soybean oil and pollack } \\
\text { liver oil }(3: 2)\end{array}$ & 10.0 & 10.0 & 10.0 \\
\hline Vitamin mixture & 1.6 & 1.6 & 1.6 \\
\hline Choline chloride & 0.5 & 0.5 & 0.5 \\
\hline Cellulose & 2.9 & 2.7 & 2.7 \\
\hline Mineral mixture ${ }^{* 3}$ & 5.0 & 5.0 & 5.0 \\
\hline Zinc supplement ${ }^{* 4}$ & - & 0.2 & 0.2 \\
\hline
\end{tabular}

${ }^{* 1}$ Crude ash 20.5\%; *2 Deboned, crude ash $16.2 \%$;

${ }^{* 3} \mathrm{Zinc}$ free; ${ }^{* 4} 20 \mathrm{mg} \quad \mathrm{Zn} / \mathrm{g} \quad\left(880 \mathrm{mg} \quad \mathrm{ZnSO}_{4} / 9.12 \mathrm{~g}\right.$

Dextrin).

the effector cells was found to be greater than $95 \%$ by the trypan blue dye exclusion method.

The target cell line used was P185 mouse mastocytoma cells. One $\times 10^{6}$ cells were labelled with 3.7 MegaBeq $\mathrm{Na}_{2}{ }^{51} \mathrm{CrO}_{4}$ (Japan Atomic Energy Research Institute) for $1.5 \mathrm{~h}$ at $37^{\circ} \mathrm{C}$. The labelled cells were washed three times with RPMI 1640 and diluted to $2 \times 10^{5} \mathrm{cells} / \mathrm{ml}$. The cell suspension $(100 \mu \mathrm{l})$ was delivered to each of the round bottom of 96 wells in a microtitre plate. Thereafter, effector cells were added to several wells, resulting in 50:1 ratio of effector to target cells. After an incubation period of $8 \mathrm{~h}$ at $20^{\circ} \mathrm{C}, 100 \mu \mathrm{l}$ of supernatant was harvested from each well and the radioactivity in the sample was measured using an automated gamma counter, Shimadzu RAW 300. Radioactivites of supernatents of target cells without effector cells and that of target cells and effector cells destroyed by a detergent $(8 \%$ 


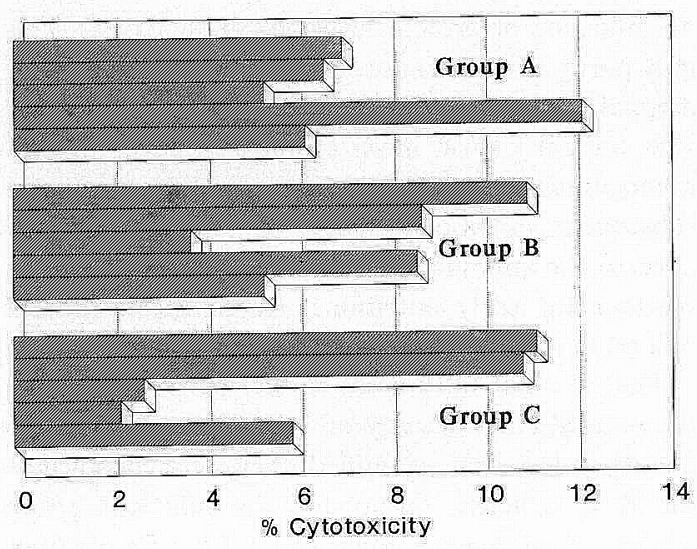

Fig. 1. Effect of dietary protein on natural-killer activity in rainbow trout. Each bar represents $\%$ cytotoxicity of individual fish. Group A, $0 \%$ protein; Group B, 35\% protein; Group C, $50 \%$ protein.

7X, ICN Biomedicals) served as spontaneous and total release controls. Each value of the ${ }^{51} \mathrm{Cr}$ release was a mean from triplicate wells and cytotoxicity percentage was calculated as follows

Cytotoxicity $\%$

$$
=\frac{\text { Test release-Spontaneous release }}{\text { Total release-Spontaneous release }} \times 100
$$

Duncan's new multiple range test was employed for comparison of the groups in the experiment.

\section{Results}

The growth of fish in the different experiments corresponded to the dietary treatments. Feed performance and growth of this species on diets similar to those of this study have already been worked out (Ogino et al., 1976; Takeuchi and Watanabe, 1977; Takeuchi et al., 1978; Satoh et al., 1987). The average final fish weights recorded in the experiments were as follows; Experiment I: Group A 140 g; Group B $270 \mathrm{~g}$; Group C $260 \mathrm{~g}$; Experiment II : Group D $99 \mathrm{~g}$; Group S $172 \mathrm{~g}$; and Experiment III, Group X $180 \mathrm{~g}$; Group Y $263 \mathrm{~g}$; and Group Z $330 \mathrm{~g}$.

The cytotoxicity of the leucocyte cells from the head kidney of rainbow trout fed different levels of protein seemed to fall in the same range (Fig. 1). The mean values for groups A, B and C were $7.56 \%$ $( \pm 2.72), 7.56 \%( \pm 2.92)$ and $6.68 \%( \pm 4.32)$, respectively. The values were not statistically different from each other. In the experiment on EFA, the

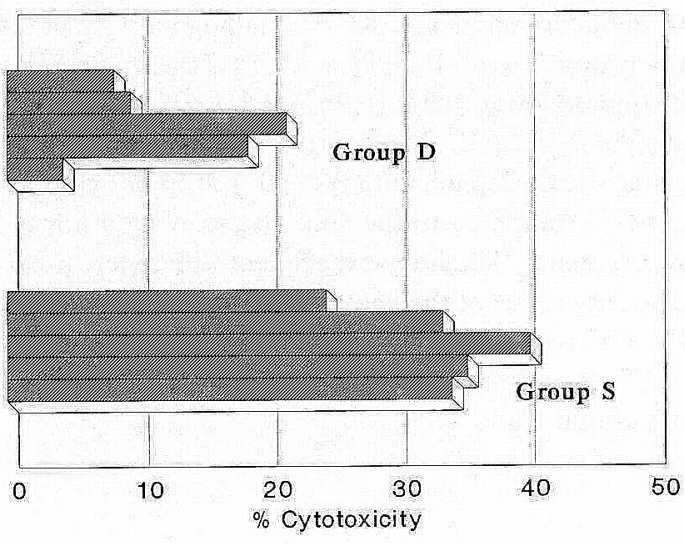

Fig. 2. Effeet of dietary essential fatty acid (EFA) on natural-killer activity in rainbow trout. Each bar represents \% cytotoxicity of individual fish. Group D, EFA deficient; Group S, EFA sufficient.

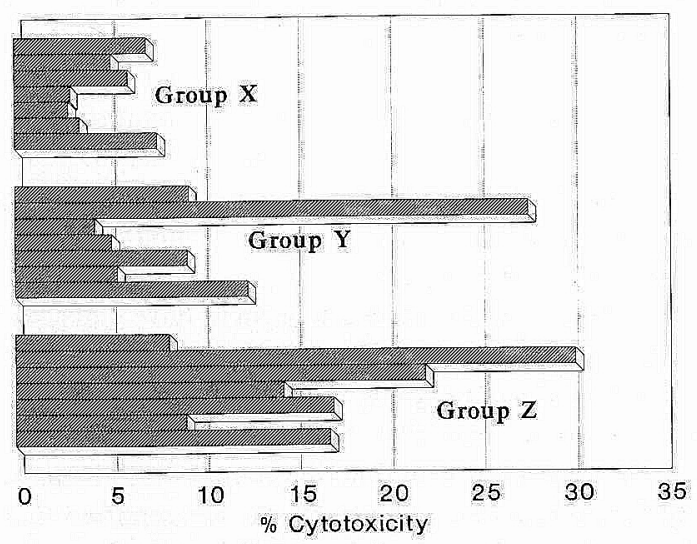

Fig. 3. Effect of dietary zinc on natural-killer aetivity in rainbow trout. Each bar represents \% cytotoxicity of individual fish. Group $X, Z n$ deficient; Group Y, Zn insufficient; Group Z, Zn sufficient.

cytotoxicity was almost trebled by supplementing $2 \%$ n-3 HUFA to the diet when compared to group D where $5 \%$ palmitic acid was the saturated lipid source (Fig. 2). The mean cytotoxicity percentage was $12.44( \pm 7.33)$ and $33.76( \pm 5.77)$ for group D and $S$, respectively. Variance analysis indicated that the difference was significant $(\mathrm{P}<0.01)$. The deficiency of zinc in the diet also seemed to reflect upon the natural killing capability of leucocytes in fish (Fig. 3); the value in the normal group was more than three times higher than that recorded $(5.07 \% \pm 1.98)$ 
in the deprived group, $X$. The killing activity noted for group $\mathrm{Y}$ was $10.59 \%$ ( \pm 8.14$)$, the value being distinctly lower than $16.96 \%( \pm 7.60)$ of the zinc sufficient group $\mathrm{Z}$. The deprivation of zinc produced a statistically significant $(P<0.01)$ drop in cytotoxic activity compared to the animals receiving a normal supplement. The inter-experiment difference in cytotoxicity levels of the leucocytes was probably due to the different origin of the rainbow trout (Gunji et $a l.)^{*}$, the animals had the same parentage within the individual trials.

\section{Discussion}

The diseased state of a living organism is often associated with malnutrition. This aspect seems true not only for man and experimental animals like rat, mice and guinea pig, but also for fish. Although some initial work on nutrition and immunocompetence in fish have identified specific and non-specific responses, there is hardly any mention on naturalkiller activity of the leucocytes. The non-specific cytotoxic activity may play a role in natural resistance to tumors or certain microbial diseases (Etchberger et al., 1987). Therefore dietary manipulation might enable the fish to attain a primary level of immunity against disease.

Protein deficiency does not seem to have a marked effect on the killing ability of the leucocytes. The almost identical range of cytotoxic activity at different dietary protein levels in this study indicates that cell mediated immune function may be uninfluenced by the protein nutrition. Earlier it was reported that humoral responses were also unaffected by the status of protein nutrition (Kiron et al., 1991). Although there is no direct information on NK activity under different dietary protein levels in higher vertebrates, some work on mice subjected to dietary restriction from the time of weaning indicated that the activity of cytotoxic T-lymphocytes was better maintained than in control (Weindruch et al., 1983). They suggest that the immune system of restricted mice may have matured less rapidly and consequently remained more functional for longer period than in well fed controls. In rainbow trout there seems to be

\footnotetext{
* Gunji, A., N. Okamoto, V. Kiron and Y. Ikeda (1992): An evaluation of the natural-killer activity of two strains of rainbow trout Oncorhynchus mykiss. In abstract of Proc. Jpn. Assoc. Dev. Comp. Immunol., 4, p. 23. (In Japanese.)
}

no influence of protein level on NK activity. This may partly be so because fish were initiated on commercial diets before feeding the experimental diets. The animals must have attained a level of immunocompetence during their earlier life period and subsequent nutritional insult or alteration hardly affected the immune functions. It has to be clarified whether the early nutritional status affects protein related immune responses.

The essential fatty acids in diet perhaps enhance the natural-killer activity of fish. Though only two dietary groups were examined, they were classified as the EFA deficient group and the sufficient group which had an excess amount of HUFA. The distinct response of the two groups confirms the fact that dietary fat modulates several aspects of immune responsiveness (Gershwin et al., 1985). DeWille et al. (1981) demonstrated that in mice fed EFA deficient diet, the T-cell immunity was rapidly reduced when compared to diets with high amounts of polyunsaturated fatty acids (PUFA). No changes in NK activity was observed by Krause et al. (1980) in rat fed different levels of lipid. However, high levels of PUFA suppressed lymphocyte function in mice when EFA requirements were met (Erickson et al., 1983). Mertin and Hughes (1975) based on human studies is of the opinion that both saturated and polyunsaturated fatty acids have inhibitory effect on lymphocyte response. PUFA may directly affect lymphocyte, being the structural components of cell membrane phospholipids (Gross and Newberne, 1980). In the present experiment we observed enhanced immune activity with the HUFA diet. This has perhaps to do with the ratio of saturated to unsaturated lipids in the diet. A related study by Weyman et al. (1975) indicated that the ratio of saturated to unsaturated fatty acids may determine the ultimate degree of inhibition on lymphocyte response.

Zinc has evidently a significant role in the NK activity of fish. The activity was substantially lower in fish receiving inadequate amounts of the trace element. Zinc is essential for the optimal function of several enzymes and cellular proliferation in the lymphoid tissues. Acquired and inherited deficiency causes lymphoid atrophy and imparied T-killer cell activity in animal models (Fernandes et al., 1979; Chandra and Au, 1980; Chandra, 1991). It was detected that aged mice had reduced natural cytotoxic activity against YAC-1 target cells. This immu- 
nological derangement was effectively improved after oral administration of zinc (Mocchegiani et al., 1990). The bioavailability of zinc may be crucial for the immune function as evidenced in this fish and might as well be age dependent.

The cytotoxic non-specific cells from the head kidney of $O$. mykiss are thus regulated by some of the components derived from nutrients. Proper diets offered at crucial stages of development contributes to an intact immunological function.

\section{Acknowledgements}

The authors express appreciation to Japanese Cancer Research Resources Bank (JCRB)-Cell for kindly provided the P815 cells. This study was supported in part by a grant in aid for scientific research from the Ministry of Education, Science and Culture in Japan (No. 05660204).

\section{References}

Blazer, V. S. and R. E. Wolke (1984): The effect of tocopherol on the immune response and non-specific resistance factors of rainbow trout (Salmo gairdneri). Aquaculture, 37, 1-9.

Chandra, R. K. (1991): Immunocompetence is a sensitive and functional barometer of nutritional status. Acta. Paediatr. Scand. Suppl., 374, 129-132.

Chandra, R. K. and B. Au (1980): Single nutrient deficiency and cell-mediated immune response. I. Zinc. Am. J. Clin. Nutr., 33, 736-738.

DeWillie, J. W., P. J. Fraker and D. R. Romsos (1981): Effects of dietary fatty acids on delayed type hypersensitivity in mice. J. Nutr., 111, 2039-2043.

Durve, V. S. and R. T. Lovell (1982): Vitamin C and disease resistance in channel catfish (Ictalurus punctatus). Can. J. Fish Aquat. Sci., 39, 948-951.

Erickson, K. L., D. A. Adams and C. J. McNeill (1983): Dietary lipid modulation of immune responsiveness. Lipids, 18, 468-474.

Etchberger, K. J., P. W. Rono and E. Moody (1987): A survey of non-specific cytotoxic activity of leukocytes in marine and freshwater fishes and agnathans. Bull. Eur. Ass. Fish Pathol., 7, 68-71.

Evans, D. L., S. S. Graves, D. Cobb and D. L. Dawe (1984): Non-specific cytotoxic cells in fish Ictalurus punctatus. II. Parameters of target cell lysis and specificity. Dev. Comp. Immunol., 8, 303-312.

Fernandes, G., M. Nair, K. Onoe, T. Tanaka, R. Floyd and R. A. Good (1979): Impairment of cell-mediated immunity functions by dietary zinc deficiency in mice. Proc.
Natl. Acad. Sci. USA., 76, 457-461.

Gershwin, M. E., R. S. Beach and L. S. Hurley (1985): "Nutrition and immunity". Academic Press, New York, $417 \mathrm{p}$.

Graves, S. S., D. L. Evans, D. Cobb and D. L. Dawe (1984): Non-specific cytotoxic cells in fish Ictalurus punctatus. I. Optimum requirements for target cell lysis. Dev. Comp. Immunol., 8, 293-302.

Gross, R. L. and P. M. Newberne (1980): Role of nutrition in immunologic function. Physiol. Rev., 60, 188302.

Hardie, L. J., T. C. Fletcher and C. J. Secombes (1990): The effect of vitamin $\mathrm{E}$ on the immune response of the atlantic salmon (Salmo salar L.). Aquaculture, 87, 1-13.

Hinuma, S., T. Abo, K. Kumagai and M. Hata (1980): The potent activity of freshwater kidney cells in cellkilling. I. Characterization and species distribution of cytotoxicity. Dev. Comp. Immunol., 4, 653-666.

Kiessling, R., E. Klein and H. Wigzell (1975): Natural killer cells in the mouse. I. Cytotoxic cells with specificity for mouse molony leukemia cells. Specificity and distribution according to genotype. Eur. J. Immunol., 5, 112-117.

Kiron, V., H. Fukuda, T. Takeuchi and T. Watanabe (1991): Dietary protein related humoral immune response and disease resistance of rainbow trout. Proc. 4th Intl. Symp. on Fish Nutrition and Feeding, June 1991; Biarritz, France.

Krause, L., M. Williams and S. A. Broitman (1980): Relationship of diet high in lipid and cholestrol on immune function in rats given 1, 2, dimethyl hydrazine (DMH). Am. J. Clin. Nutr., 33, 937-940.

Lall, S. P., G. Oliver, D. E. M. Weerakoon and J. A. Hines (1990): The effect of vitamin C deficiency and excess on the immune response in Atlantic salmon (Salmo salar L.). In "The Current status of fish nutrition in aquaculture" (ed. by M. Takeda and T. Watanabe). Japan Translation Centre, Tokyo. pp. 427-441.

Li, Y. and R. T. Lovell (1985): Elevated levels of dietary ascorbic acid increase immune responses in channel catfish. J. Nutr., 115, 123-131.

Mertin, J. and D. Hughes (1975): Specific inhibitory action of polyunsaturated fatty acid on lymphocyte transformation induced by PHA and PPD. Int. Arch. Allergy Appl. Immunol., 48, 203-210.

Mocchegiani, E., M. Muzzioli and N. Fabris (1990): Effect of dietary zinc supplementation on immune function in aging mice. Proc. 7th Intl. Symp. on Trace elements in Man and Animals, May 1990; Dubrovnik, Yugoslavia, pp. 31.8-31.9.

Morita, N., H. Fukuda and T. Sano (1989): The suitability of K 562 and Molt-4 to cytotoxic assay in common carp (Cyprinus carpio). Bull. Eur. Ass. Fish Pathol., 9, 55-57. Ogino,C., J. Y. Chiou and T. Takeuchi (1976): Protein 
nutrition in fish. IV. Effects of dietary energy on the utilization of protein by rainbow trout and carp. Nippon Suisan Gakkaishi, 42, 213-218.

Rook, G. (1989): Immunity to viruses, bacteria and fungi. In "Immunology" (ed. by I. Roitt, J. Brostoff and D. Male). Gower Medical Pub., London. pp. 16.1-16.16.

Sakai, D. K. (1983): Tentative observations of cytotoxic circulating lymphocytes present in rainbow trout immunized with a cell cultured antigen. Nippon Suisan Gakkaishi, 50, 403-408.

Satoh, S., K. Izume, T. Takeuchi and T. Watanabe (1987): Availability to rainbow trout of zinc contained in various types of fish meals. Nippon Suisan Gakkaishi, 53, 18611866.

Scarpa, J., D. M. Gatlin III and D. H. Lewis (1992): Effects of dietary zinc and calcium on select immune functions of channel catfish. J. Aquat. Anim. Health, 4, 24-31.

Sheldon, W. M. Jr. and V. S. Blazer (1991): Influence of dietary lipid and temperature on bactericidal activity of channel catfish macrophages. J. Aquat. Anim. Health, 3, 87-93.

Takeuchi, T. and T. Watanabe (1977): Dietary levels of methyl laurate and essential fatty acid requirement of rainbow trout. Nippon Suisan Gakkaishi, 43, 893-898.

Takeuchi, T., T. Watanabe and C. Ogino (1978): Optimum ratio of protein to lipid in diets of rainbow trout. Nippon Suisan Gakkaishi, 44, 683-688.

Weindruch, R. H., B. H. Devens, H. V. Raff and R. L. Walford (1983): Influence of dietary restriction and aging on natural-killer cell activity in mice. J. Immunol., 130, 993-998.

Weyman, C., J. Belin, A. D. Smith and R. H. S. Thompson (1975): Linoleic acid as an immunosuppressive agent. Lancet, 2, 33.

Zarling, J. M., R. C. Nowinsky and F. H. Bach (1975): Lysis of leukemia cells of normal mice. Proc. Natl. Acad. Sci. USA., 72, 2780-2784. 